\title{
A Review of Instruments for Assessing Body Image in Preschoolers
}

\author{
Cuesta-Zamora, Cristina ${ }^{1, *}$, Navas, Leandro ${ }^{2}$ \\ ${ }^{1}$ Department of Music, Arts Education and Physical Education, Castilla-La Mancha University, Spain \\ ${ }^{2}$ Department of Developmental and Educational Psychology, University of Alicante, Spain
}

Copyright $\mathrm{O} 2017$ by authors, all rights reserved. Authors agree that this article remains permanently open access under the terms of the Creative Commons Attribution License 4.0 International License

\begin{abstract}
Society has produced many idealized and unattainable standards of beauty. These may be internalized by young children, increasing the risk of body dissatisfaction, which is the strongest predictor of eating disorders. Prompted by this concern, the aim of the present research was to identify and analyze the instruments that have been used to measure body perception and body dissatisfaction in preschoolers. To this end, we reviewed 18 articles published between 2005 and 2017 and retrieved from the PsycINFO and MEDLINE databases. Our results indicated that the instruments used to assess body image comprise silhouette scales, interviews and questionnaires. The results suggest that body dissatisfaction is higher when assessed with silhouette scales compared to questionnaires and interviews in preschoolers. When developing instruments to assess preschoolers' body image, it is important to take their cognitive development into account.
\end{abstract}

Keywords Body Image, Body Dissatisfaction, Body Perception, Preschoolers, Instruments, Literature Review

\section{Introduction}

Body image is a multifaceted construct that includes perceptions of appearance, feelings and thoughts about the body, and the effect of these on the body's functions and capabilities [1, 2]. Gardner [3] has distinguished two components of body image. The perceptual component refers to the mental representation of our own body and its characteristics. The attitudinal component refers to the feelings we have about our body image and physical appearance.

In many present-day societies, thinness is perceived as a synonym of beauty and attractiveness [4] and the concept of overweight is surrounded by many prejudices and stereotypes [5]. These ideals of beauty and stereotypes can be internalized by preschool children [5-9], arousing concerns $[10,11]$ and negative opinions and feelings [12-14] about their bodies. Body dissatisfaction has been observed in children aged between 4 and 7 [7, 8, 12-26]. In a recent review on the subject, Tatangelo et al. [27] found that the prevalence of body dissatisfaction in children aged under 6 years old ranged between $20 \%$ and $70 \%$, depending on the assessment instrument employed. In fact, the term "normative discontent", which refers to the high prevalence among women that are dissatisfied with their bodies due to the pursuit of thinness [28], could also be applied to 5-year old children $[16,17]$.

The study of body dissatisfaction in preschoolers is important for various reasons. First, body dissatisfaction is the strongest predictor of eating disorders in adolescents [29]. Second, the age of onset of eating disorders is decreasing, developing in some cases before adolescence [30]. In fact, children aged five to 13 years present a high prevalence of early onset of eating disorders, associated with similar psychological symptoms to those of adults with eating disorders [31]. Third, body dissatisfaction and the desire for thinness could have a negative impact on the development of self-esteem [17]. Lastly, body dissatisfaction is associated with increased symptoms of depression in adolescents [11, 32].

It is therefore essential to determine whether preschool children present body image distortion and body dissatisfaction, and if this is a predictor of eating disorders or body dimorphic disorder at older ages [18]. However, this requires developing valid and reliable instruments for preschool children [33]. The young age of participants has hampered assessment of their body image, generating inconsistent ideas about when body dissatisfaction develops and the possible psychosocial consequences [7].

\section{Objective}

Given the above, the main objective of this review was to provide a comprehensive overview of the instruments employed to assess body image in children aged between 3 and 6 years old. 


\section{Methods}

\subsection{Inclusion and Exclusion Criteria}

Inclusion criteria were: a) published in English or Spanish; b) focused on assessment of the relationship between body image in preschoolers. Because our goal is to determine the instruments used to assess body image in preschool children, we have also included experimental studies that evaluate body image. In this line, Hayes and Tantlef-Dunn [12] used a scale and an interview to evaluate body image and the effects of media in body image, while Dittmar, Halliwell and Ive [34] assessed whether Barbies could be a possible cause of girls' body dissatisfaction; c) the mean age of the participants must have been between 3 and 6 years, unless data were analyzed and reported for an preschool-group within a large sample. In this case, the number of preschoolers must have been specified. For example, Li et al. [25] examined body image among 2402 children aged 3-6.

Exclusion criteria were: a) published before 2005; b) literature review; c) focused on assessment programs about body image; h) assessment of body image is not described.

\subsection{Search Strategy}

The key constructs selected in accordance with the research objectives were "body image", "body size estimation", "body dissatisfaction", "body size", "satisfaction with body image", "preschool child*", "child* and "young child*". Different search strategies were used with the key words to collect the articles. Boolean search operators were used to specify the relations between the different constructs (e.g., ("body image" OR "body dissatisfaction") AND "preschool child"). Asterisks were also added to the required key concepts, so as to include in the results words with the same stem as the concept, but with different suffixes (e.g., *satisfaction, to include words such as dissatisfaction, etc.).

\subsection{Procedure}

In order to select the articles, we read the title, keywords and the abstract of each article. Figure 1 shows an adaptation of PRIMA flow diagram [35] of search process. A total of 18 articles fulfilled our research objectives.

\section{Results}

\subsection{Silhouette Scales for Assessing Body Perception and Body Dissatisfaction}

Silhouette scales are often used to assess body satisfaction and perceived appearance in children $[6,10,36]$. Current and ideal body size are often assessed by asking the child which figure reflects his or her current size and the figure he or she would like to have [18].

Meanwhile, perceptions of body size are assessed by examining the differences between current body image and perceived image. A discrepancy close to 0 means that the child's perceived body size is appropriate, but if there is a significant discrepancy [3], this indicates a distorted body image or an inappropriate perception of it. Distortion can be positive (when the body is perceived to be larger than it actually is) or negative (when the body is perceived to be smaller than it actually is). The attitudinal component of body image is assessed by asking participants to adjust their current image to their idealized (or preferred) image. Again, the discrepancy between current image and idealized image is calculated, and a difference of 0 indicates body satisfaction whereas a difference between the two suggests body dissatisfaction [18]. These scales have also served as a means to measure other variables, such as ideals of beauty and prejudice against obesity in preschoolers.
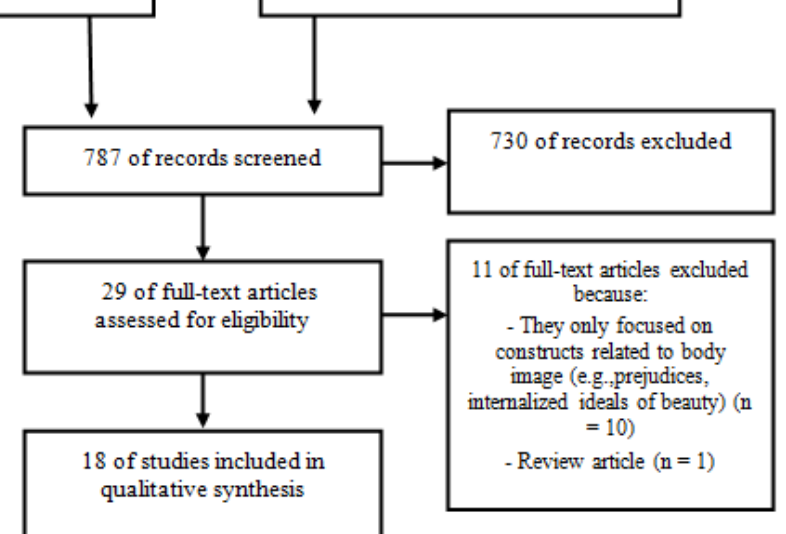

Figure 1. Review search process. 
The Collins Figure Rating Scale [36], consisting of seven silhouettes ordered linearly from the smallest to largest body size, is a commonly used method to assess body perception and satisfaction in preschool children [4, 14, 34, 37]. In addition, the scale has been adapted by adding more figures $[9,23]$ or changing facial features [25]. Other silhouette scales that have been used besides the Collins Scale [36] include those developed by Tiggemann and Pennington [38],
Tiggemann and Wilson-Barret [39], Truby and Paxton [40] and Mciza, Goedecke, Steyn, Charlton and Puoane [41], or adaptations of the same [7, 20,21, 42, 43], as well as scales designed and created specifically for the paediatric population $[12,19]$. Table 1 shows the silhouette scales used in studies over the past 12 years in children aged 3 to 6 years old. Table 4 shows the main results obtained using the scales.

Table 1. Silhouette scales used to assess body image in preschoolers

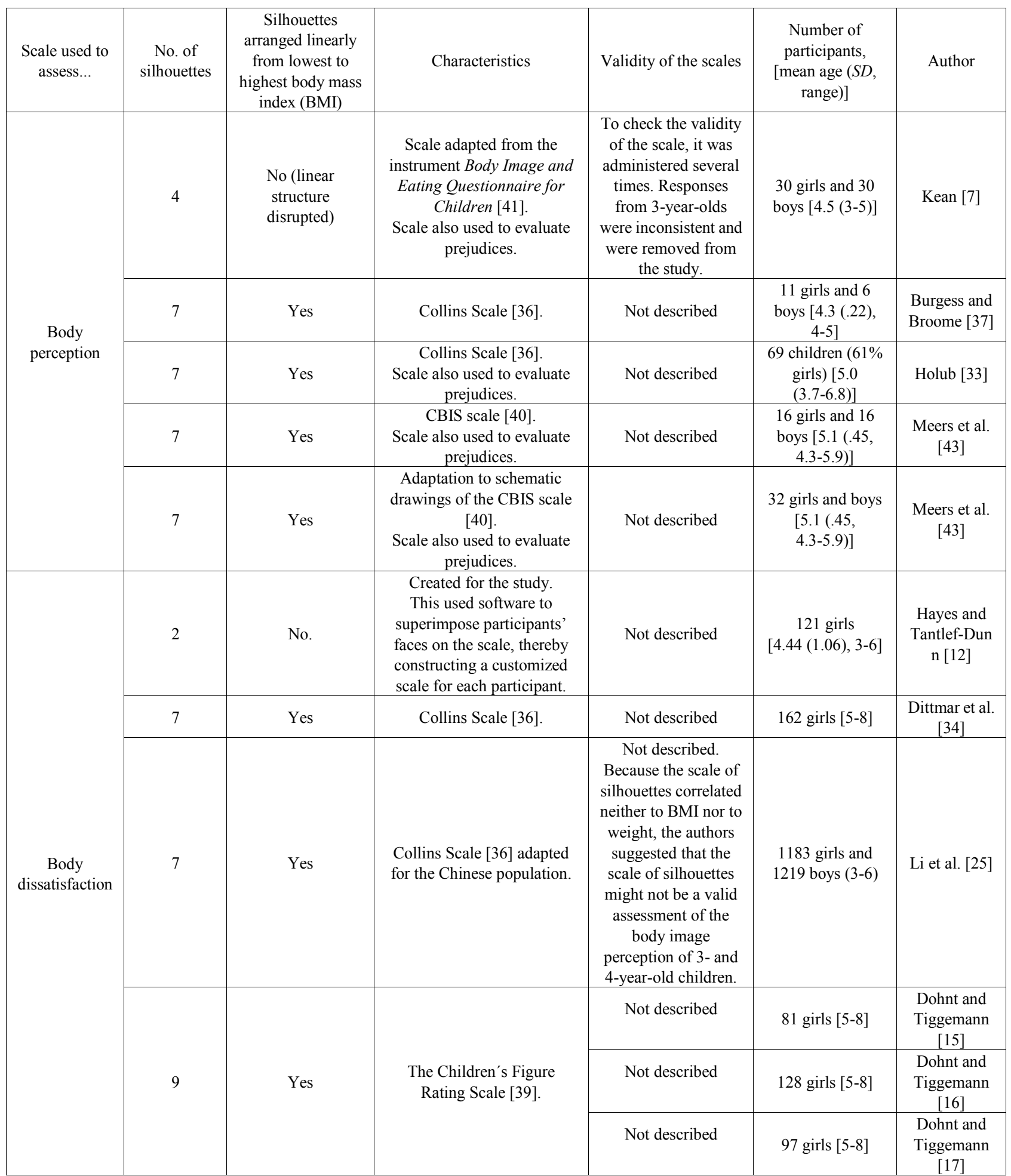




\begin{tabular}{|c|c|c|c|c|c|c|}
\hline & \multirow[t]{2}{*}{5} & \multirow[t]{2}{*}{ Yes } & \multirow{2}{*}{$\begin{array}{l}\text { Adaptation of the } \\
\text { Tiggemann and Pennington } \\
\text { scale [38]; The scale was } \\
\text { created using colored felt } \\
\text { fabric; Children could } \\
\text { choose the hair color that } \\
\text { closely matched their own. } \\
\text { Scale also used to evaluate } \\
\text { body size attitudes. }\end{array}$} & \multirow{2}{*}{$\begin{array}{l}\text { ICC analyzes showed } \\
\text { a significant } \\
\text { agreement between } \\
\text { test (T1) and retest } \\
\text { (T2) for current } \\
\text { figure selection (ICC } \\
=.58, p=.03 \text { ) and } \\
\text { ideal figure selection } \\
\text { (ICC =.58, } p=.03) \\
{[44] .}\end{array}$} & $\begin{array}{c}152 \text { girls and } 127 \\
\text { boys [4.49(4 } \\
\text { years-old)] }\end{array}$ & $\begin{array}{c}\text { Damiano, } \\
\text { Gregg, } \\
\text { Spiel, } \\
\text { McLean, } \\
\text { Wertheim } \\
\text { and Paxton } \\
\text { [20]; }\end{array}$ \\
\hline & & & & & $\begin{array}{l}111 \text { girls }[5.42 \\
(.32,5 \text { years-old })\end{array}$ & $\begin{array}{c}\text { Damiano et } \\
\text { al. [21] }\end{array}$ \\
\hline \multirow[t]{4}{*}{$\begin{array}{c}\text { Body } \\
\text { perception } \\
\text { and body } \\
\text { dissatisfaction }\end{array}$} & 3 & Yes & Created for the study. & $\begin{array}{l}\text { Research compared } \\
\text { children's } \\
\text { performance on } 3 \\
\text { tasks (body part } \\
\text { identification, animal } \\
\text { stimulus, current } \\
\text { body size perceptions } \\
\text { and ideal body size). } \\
\text { From } 81 \% \text { to } 96 \% \text { of } \\
\text { the children } \\
\text { completed the tasks } \\
\text { without help from the } \\
\text { experimenter. }\end{array}$ & $\begin{array}{l}68 \text { girls and } 76 \\
\text { boys [52 months } \\
\text { (11 months), 3-5] }\end{array}$ & $\begin{array}{l}\text { Tremblay et } \\
\text { al. [19] }\end{array}$ \\
\hline & 8 & Yes & $\begin{array}{l}\text { Adaptation of the Collins } \\
\text { Scale [36]. }\end{array}$ & Not described & $\begin{array}{l}225 \text { girls and } 246 \\
\text { boys [4-6] }\end{array}$ & $\begin{array}{l}\text { Makalesi et } \\
\text { al. [23] }\end{array}$ \\
\hline & 9 & Yes & $\begin{array}{l}\text { Collins Scale [36] adapted } \\
\text { by Rand and Resnick [45]. }\end{array}$ & Not described & $\begin{array}{c}296 \text { boys and } 278 \\
\text { girls [6.5 (.6), } \\
5-7]\end{array}$ & $\begin{array}{c}\text { Pallan et al. } \\
\text { [26] }\end{array}$ \\
\hline & 9 & $\begin{array}{l}\text { No (each figure on } \\
\text { a blank page) }\end{array}$ & $\begin{array}{l}\text { Adapted from Tiggemann } \\
\text { and Pennington [38]. }\end{array}$ & Not described & $\begin{array}{l}22 \text { girls and } 25 \\
\text { boys [4-6] }\end{array}$ & $\begin{array}{c}\text { Birbeck and } \\
\text { Drummond } \\
{[42]}\end{array}$ \\
\hline
\end{tabular}

Table 2. Questionnaires to evaluate body image in preschoolers

\begin{tabular}{|c|c|c|c|c|c|}
\hline $\begin{array}{c}\text { Questionnaire } \\
\text { used to } \\
\text { assess... }\end{array}$ & $\begin{array}{c}\text { Number of } \\
\text { participants, } \\
\text { [mean age ( } S D, \\
\text { range) }]\end{array}$ & $\begin{array}{l}\text { Number } \\
\text { of items }\end{array}$ & Characteristics & $\begin{array}{l}\text { Validity of the } \\
\text { instrument }\end{array}$ & Author \\
\hline \multirow[b]{2}{*}{$\begin{array}{c}\text { Body } \\
\text { dissatisfaction }\end{array}$} & 162 girls [5-8] & 9 & $\begin{array}{c}\text { Adaptation of } 9 \text { items from the Revised Body-Esteem Scale } \\
\text { questionnaire [46]. }\end{array}$ & $\begin{array}{l}\text { The questionnaire } \\
\text { presented a good } \\
\text { internal } \\
\text { consistency } \\
\text { coefficient }(\alpha \\
=.71) \text { for all } \\
\text { participants. }\end{array}$ & $\begin{array}{l}\text { Dittmar } \\
\text { et al.[34] }\end{array}$ \\
\hline & $\begin{array}{l}128 \text { girls [5-8] in } \\
\text { Dohnt and } \\
\text { Tiggemann [16] } \\
97 \text { girls [5-8] in } \\
\text { Dohnt and } \\
\text { Tiggemann [17] }\end{array}$ & 2 & $\begin{array}{l}\text { Based on the format of the Pictorical Scale of Perceived } \\
\text { Competence/Social Acceptance employed by Harter and Pike } \\
\text { [47] with preschoolers, the authors developed a pictorial } \\
\text { scale to assess satisfaction with appearance in girls. To } \\
\text { introduce the girls to the task, they were first shown two } \\
\text { images. One image depicted a girl who was happy with the } \\
\text { way she looked at that moment while the other showed a girl } \\
\text { who was not happy with the way she looked at that moment. } \\
\text { Then, the girls had to select the girl who most closely } \\
\text { resembled them, and finally they were asked a question about } \\
\text { whether they felt happy with their appearance. The responses } \\
\text { are scored on a Likert scale from } 1 \text { to } 4(1=\text { always not happy, } \\
2=\text { usually not happy, } 3=\text { usually happy, } 4=\text { always happy). }\end{array}$ & Not described & $\begin{array}{c}\text { Dohnt } \\
\text { and } \\
\text { Tiggema } \\
\text { nn [16, } \\
17]\end{array}$ \\
\hline
\end{tabular}

\subsection{Questionnaires to Assess Body Image}

Only two studies have used questionnaires to evaluate body image (see Table 2). The main results obtained through questionnaires are found in Table 4. 


\subsection{Qualitative Research and Body Image}

There are only 4 articles analyzing body image from a qualitative perspective (see Table 3 ).

Table 3. Body image evaluated from a qualitative perspective

\begin{tabular}{|c|c|c|c|c|c|}
\hline $\begin{array}{l}\text { Assessment } \\
\text { of... }\end{array}$ & $\begin{array}{l}\text { Number of } \\
\text { participants, } \\
\text { [mean age } \\
(S D, \text { range })]\end{array}$ & Method & Description & Results & Author \\
\hline $\begin{array}{c}\text { Body } \\
\text { perception }\end{array}$ & $\begin{array}{l}22 \text { girls and } \\
25 \text { boys } \\
{[4-6]}\end{array}$ & Interview & $\begin{array}{l}\text { The aim of the interview was to explore how } \\
\text { children perceived their own body image and } \\
\text { that of others, and to explore different } \\
\text { concepts related to health. }\end{array}$ & $\begin{array}{l}\text { - In girls, the notion of thinness } \\
\text { as a desirable physical trait was } \\
\text { prevalent. } \\
\text { - In boys, the ideal was for a } \\
\text { larger physique. Maybe, } \\
\text { because they identified that a } \\
\text { larger body size provides them } \\
\text { with a practical advantage. }\end{array}$ & $\begin{array}{l}\text { Birbeck and } \\
\text { Drummond } \\
\quad[42]\end{array}$ \\
\hline \multirow{3}{*}{$\begin{array}{c}\text { Body } \\
\text { dissatisfaction }\end{array}$} & $\begin{array}{l}151 \text { girls } \\
{[5.91(.86} \\
5-7)]\end{array}$ & Interview & $\begin{array}{l}\text { Adaptation of the Body Part Satisfaction } \\
\text { Scale instrument, which has been widely } \\
\text { validated in adult women and adolescent } \\
\text { girls. In the interview, the girls were stood in } \\
\text { front of a mirror and asked whether they liked } \\
\text { or did not like different parts of their body. } \\
\text { Body satisfaction was calculated using the } \\
\text { number of positive comments that } \\
\text { participants made about their body during the } \\
\text { individual mirror exercise. Body } \\
\text { dissatisfaction was calculated using the } \\
\text { number of negative comments. } \\
\text { The instrument has been validated in children } \\
\text { aged } 5 \text { to } 7 \text { years old, but the study has not yet } \\
\text { been published [48]. }\end{array}$ & $\begin{array}{l}\text { - Mean of positive comments } \\
\text { about body (body satisfaction) }= \\
6.23(S D=2.87) \text {. } \\
\text { - Mean of negative comments } \\
\text { about body (body } \\
\text { dissatisfaction) }=1.59(S D= \\
1.94) \text {. }\end{array}$ & $\begin{array}{c}\text { Pérez et al. } \\
{[14]}\end{array}$ \\
\hline & $\begin{array}{c}121 \text { girls } \\
{[4.44(1.06)} \\
3-6]\end{array}$ & Interview & $\begin{array}{l}\text { Explore about children appearance } \\
\text { satisfaction. } \\
\text { Children were shown a visual scale with } 3 \\
\text { response options (never or almost never, } \\
\text { sometimes, and nearly all the time) in order to } \\
\text { facilitate the activity. }\end{array}$ & $\begin{array}{l}\text { - All but three participants liked } \\
\text { the way they looked. } \\
-24.8 \% \text { of participants } \\
\text { indicated that } \\
\text { they disliked something about } \\
\text { their physical appearance (e.g., } \\
\text { hair, skin color, and body part). } \\
\text { - } 30.6 \% \text { of girls noted that they } \\
\text { would change something about } \\
\text { their physical appearance. }\end{array}$ & $\begin{array}{l}\text { Hayes and } \\
\text { Tantlef-Du } \\
\text { nn [12] }\end{array}$ \\
\hline & $\begin{array}{l}29 \text { girls and } \\
24 \text { boys }[4 \\
\text { years] }\end{array}$ & Observation & $\begin{array}{l}\text { Interviewers observed children in a play room } \\
\text { for four hours. The research assistants } \\
\text { checked off the children's behaviors and } \\
\text { comments regarding bodies, food or clothing. }\end{array}$ & $\begin{array}{l}\text { Although four-year-old girls } \\
\text { express concerns about weight } \\
\text { and boys about muscles, these } \\
\text { concerns do not appear to } \\
\text { impact on their general level of } \\
\text { happiness. }\end{array}$ & $\begin{array}{l}\text { McCabe et } \\
\text { al. [13] }\end{array}$ \\
\hline
\end{tabular}


Table 4. Main results of studies that have evaluated body image with scales and questionnaires

\begin{tabular}{|c|c|c|c|c|}
\hline Results about & \multicolumn{2}{|r|}{ Related to } & Results & Author \\
\hline \multirow{15}{*}{$\begin{array}{l}\text { Body } \\
\text { perception }\end{array}$} & \multirow{3}{*}{$\begin{array}{l}\text { Do children } \\
\text { perceive } \\
\text { their body } \\
\text { image } \\
\text { accurately? }\end{array}$} & \multirow{2}{*}{$\begin{array}{l}\text { Inaccurate perception } \\
\text { of their body size }\end{array}$} & $\begin{array}{c}\text { The majority of children selected figures that were thinner } \\
\text { than their current BMI with both photographic scales }(64.3 \%) \\
\text { and line-drawn scales }(71.4 \%) \text {. }\end{array}$ & Meers et al. [43] \\
\hline & & & $\begin{array}{l}\text { Only } 58.8 \% \text { chose the body shape that accurately estimated } \\
\text { their current BMI. }\end{array}$ & $\begin{array}{l}\text { Burgess and } \\
\text { Broome [37] }\end{array}$ \\
\hline & & $\begin{array}{l}\text { Differences in } \\
\text { accordance with BMI }\end{array}$ & $\begin{array}{l}\text { There was a higher prevalence of overweight children }(85 \%) \\
\text { who inadequately perceived the size of their bodies compared } \\
\text { to normal weight children }(58 \%) \text {. }\end{array}$ & Tremblay et al. [19] \\
\hline & \multirow{3}{*}{$\begin{array}{l}\text { Weight } \\
\text { status }\end{array}$} & Correlations & $\begin{array}{l}\text { Current self-perceived body size in girls and boys above } 4 \\
\text { years old (the correlation coefficients ranged from } .14 \text { to } .36 \text { ) } \\
\text { correlated with weight status. }\end{array}$ & Li et al. [25] \\
\hline & & Not correlations & $\begin{array}{c}\text { The correlation between weight status and perceived body } \\
\text { size was not significant. }\end{array}$ & Holub [33] \\
\hline & & Gender differences & $\begin{array}{l}\text { In girls (but not in boys), there were positive associations } \\
\text { between weight status and self- perception image size. }\end{array}$ & Pallan et al. [26] \\
\hline & \multirow{3}{*}{ BMI } & \multirow[b]{2}{*}{ Correlations } & $\begin{array}{l}\text { Lower BMI was significantly associated with thinner "self" } \\
\text { image size perception. }\end{array}$ & Pallan et al. [26] \\
\hline & & & $\begin{array}{l}\text { Current self-perceived body size in boys and girls above } 5 \\
\text { years old (the correlation coefficients ranged from } .22 \text { to } .41 \text { ) } \\
\text { was positive correlated to BMI. }\end{array}$ & Li et al. [25] \\
\hline & & Not correlations & $\begin{array}{l}\text { The perceived body image was not correlated to current BMI } \\
\text { when using the photographic scale or line-drawn scale. }\end{array}$ & Meers et al. [43] \\
\hline & \multirow{4}{*}{$\begin{array}{l}\text { Ideal body } \\
\text { image }\end{array}$} & \multirow{2}{*}{$\begin{array}{l}\text { Differences between } \\
\text { perceived body size } \\
\text { and ideal body size }\end{array}$} & $\begin{array}{c}\text { The ideal body size was lower than that for perceived image } \\
\text { size. }\end{array}$ & Pallan et al. [26] \\
\hline & & & $\begin{array}{l}\text { The mean perceived body size was significantly smaller than } \\
\text { the ideal figure selection. }\end{array}$ & Damiano et al. [20] \\
\hline & & Gender differences & Girls had a lower median score than boys. & Pallan et al. [26] \\
\hline & & Weight status & $\begin{array}{l}\text { BMI was significantly and positively associated with thinner } \\
\text { ideal self-perception scores. }\end{array}$ & Pallan et al. [26] \\
\hline & \multirow{2}{*}{\multicolumn{2}{|c|}{ Anti-fat attitudes }} & $\begin{array}{l}\text { Children who perceived themselves as heavier rated the } \\
\text { overweight figure more positively. }\end{array}$ & Holub [33] \\
\hline & & & $\begin{array}{l}\text { Perception of a thinner body was associated with more } \\
\text { anti-fat attitudes than perception of a large body size. }\end{array}$ & Holub [33] \\
\hline \multirow{8}{*}{$\begin{array}{l}\text { Body } \\
\text { dissatisfaction }\end{array}$} & \multirow{7}{*}{ Prevalence } & \multirow{6}{*}{ With scales } & $\begin{array}{l}55 \% \text { of the children wanted to look like a figure different } \\
\text { from their own ( } 25 \% \text { wanted to } \\
\text { look thicker and } 30 \% \text { wanted to look thinner). }\end{array}$ & Kean [7] \\
\hline & & & $\begin{array}{c}27.8 \% \text { of boys wished to be a different body size (of which } \\
22.9 \% \text { wanted to look thinner and } 77.1 \% \text { wanted to be larger). } \\
\text { Of girls, } 37.7 \% \text { wished to be a different size (of which } 35.1 \% \\
\text { wanted to be thinner and } 64.9 \% \text { wanted to have a larger } \\
\text { body). }\end{array}$ & Damiano et al. [20] \\
\hline & & & $\begin{array}{l}28.8 \% \text { of girls were dissatisfied with their body size }(15.3 \% \\
\text { wanted to be thinner, and } 13.5 \% \text { wanted to be larger). }\end{array}$ & Damiano et al. [21] \\
\hline & & & $82 \%$ were dissatisfied with their body size. & Pallan et al. [26] \\
\hline & & & $49.6 \%$ of the girls wanted to have a thinner body. & $\begin{array}{c}\text { Dohnt and } \\
\text { Tiggemann [15] }\end{array}$ \\
\hline & & & $42 \%$ of the girls wanted to have a thinner body. & $\begin{array}{c}\text { Dohnt and } \\
\text { Tiggemann [16] }\end{array}$ \\
\hline & & With questionnaire $(*)$ & $\begin{array}{l}(*) 45 \% \text { of the girls were 'always' happy with their } \\
\text { appearance, and } 48 \% \text { were 'usually' happy with the way they } \\
\text { looked. No girl reported being 'always' unhappy with the way } \\
\text { they looked. }\end{array}$ & $\begin{array}{l}\text { Dohnt and } \\
\text { Tiggemann [16] }\end{array}$ \\
\hline & Body esteem & Correlations & $\begin{array}{l}\text { Body shape discrepancies were significantly related to overall } \\
\text { body esteem. }\end{array}$ & Dittmar et al. [34] \\
\hline
\end{tabular}




\begin{tabular}{|c|c|c|c|}
\hline \multirow{6}{*}{ Self-esteem } & \multirow{3}{*}{ Desire for thinness } & $\begin{array}{l}\text { Body dissatisfaction was not significantly related to } \\
\text { self-esteem. }\end{array}$ & $\begin{array}{c}\text { Dohnt and } \\
\text { Tiggemann [16] }\end{array}$ \\
\hline & & $\begin{array}{l}\text { The desire for thinness was significantly associated with } \\
\text { self-esteem evaluated one year later }(r=-.24, p<.05) \text {. }\end{array}$ & $\begin{array}{c}\text { Dohnt and } \\
\text { Tiggemann [17] }\end{array}$ \\
\hline & & $\begin{array}{l}\text { The desire for thinness significantly predicted decrease in } \\
\text { self-esteem evaluated one year later. }\end{array}$ & $\begin{array}{c}\text { Dohnt and } \\
\text { Tiggemann [17] }\end{array}$ \\
\hline & \multirow{3}{*}{$\begin{array}{c}\text { Appearance } \\
\text { satisfaction (a affective } \\
\text { measure of body image } \\
\text { assessed by } \\
\text { questionnaire) }\left({ }^{*}\right)\end{array}$} & $\begin{array}{c}(*) \text { The relationship between appearance satisfaction and } \\
\text { self-esteem was significant }(r=.48, p<.01) .\end{array}$ & $\begin{array}{c}\text { Dohnt and } \\
\text { Tiggemann [16] }\end{array}$ \\
\hline & & $\begin{array}{l}(*) \text { Appearance satisfaction correlated with self-esteem } \\
\text { evaluated one year later }(r=.21, p<.05) .\end{array}$ & $\begin{array}{c}\text { Dohnt and } \\
\text { Tiggemann [17] }\end{array}$ \\
\hline & & $\begin{array}{l}(*) \text { Appearance satisfaction did not significantly predict } \\
\text { change in self-esteem evaluated one year later. }\end{array}$ & $\begin{array}{c}\text { Dohnt and } \\
\text { Tiggemann [17] }\end{array}$ \\
\hline \multirow{3}{*}{$\begin{array}{l}\text { Peer`s body } \\
\text { dissatisfaction }\end{array}$} & Correlations & $\begin{array}{c}\text { Girl' perceptions of their peers' body dissatisfaction was } \\
\text { positively related to their own level of body dissatisfaction }(r \\
=.39, p<.01)\end{array}$ & $\begin{array}{l}\text { Dohnt and } \\
\text { Tiggemann [15] }\end{array}$ \\
\hline & \multirow{2}{*}{$\begin{array}{l}\text { Possible predictor } \\
\text { variable }\end{array}$} & $\begin{array}{l}\text { Both BMI and girl' perceptions of their peers' body } \\
\text { dissatisfaction predicted } 29.9 \% \text { of variance in body } \\
\text { dissatisfaction. }\end{array}$ & $\begin{array}{c}\text { Dohnt and } \\
\text { Tiggemann [15] }\end{array}$ \\
\hline & & $\begin{array}{l}\text { Both BMI and girl' perceptions of their peers' body } \\
\text { dissatisfaction predicted } 23 \% \text { of variance in body } \\
\text { dissatisfaction. }\end{array}$ & $\begin{array}{l}\text { Dohnt and } \\
\text { Tiggemann [16] }\end{array}$ \\
\hline $\begin{array}{l}\text { Scales and } \\
\text { questionnair } \\
\text { e to assess } \\
\text { body image }\end{array}$ & Not correlations & $\begin{array}{l}\text { The relationship between body dissatisfaction (evaluated by } \\
\text { scales) and appearance satisfaction (evaluated with } \\
\text { questionnaire) was not significant. }\end{array}$ & $\begin{array}{l}\text { Dohnt and } \\
\text { Tiggemann [16] }\end{array}$ \\
\hline \multirow{3}{*}{$\begin{array}{l}\text { Weight } \\
\text { status }\end{array}$} & \multirow[t]{2}{*}{ Positive correlations } & $\begin{array}{l}\text { Body dissatisfaction scores were significantly related to } \\
\text { weight status in both boys above } 5 \text { years old (the correlation } \\
\text { coefficients ranged from } .18 \text { to } .33 \text { ) and girls above } 3 \text { years } \\
\text { old (the correlation coefficients ranged from } .14 \text { to } .28 \text { ). }\end{array}$ & Li et al. [25] \\
\hline & & $\begin{array}{l}\text { Body satisfaction was significantly associated with weight } \\
\text { status in girls. }\end{array}$ & Tremblay et al. [19] \\
\hline & No associations & $\begin{array}{l}\text { There is no association between body dissatisfaction and } \\
\text { weight status in boys. }\end{array}$ & Tremblay et al. [19] \\
\hline \multirow{3}{*}{ BMI } & \multirow{3}{*}{ Positive associations } & \multirow{2}{*}{$\begin{array}{l}\text { Body dissatisfaction score was positively associated with } \\
\text { BMI. }\end{array}$} & Pallan et al. [26] \\
\hline & & & $\begin{array}{c}\text { Dohnt and } \\
\text { Tiggemann [15] }\end{array}$ \\
\hline & & $\begin{array}{l}\text { Body dissatisfaction scores were significantly related to BMI } \\
\text { in both boys and girls aged over } 5 \text { years (the correlation } \\
\text { coefficients ranged from } .14 \text { to } .33 \text { ). }\end{array}$ & Li et al. [25] \\
\hline \multirow{2}{*}{$\begin{array}{l}\text { Dieting } \\
\text { awareness }\end{array}$} & Dieting awareness & $\begin{array}{l}\text { Body dissatisfaction score was positively associated with } \\
\text { dieting awareness }(r=.22, p<.05) \text {. }\end{array}$ & $\begin{array}{c}\text { Dohnt and } \\
\text { Tiggemann [15] }\end{array}$ \\
\hline & Dietary restraint & Body dissatisfaction was not associated with dietary restraint. & Damiano et al. [21] \\
\hline \multirow{3}{*}{ Age } & \multirow{3}{*}{ Correlations } & \multirow{3}{*}{ Body dissatisfaction score was positively associated with age. } & Pallan et al. [26] \\
\hline & & & Dittmar et al. [34] \\
\hline & & & $\begin{array}{c}\text { Dohnt and } \\
\text { Tiggemann [15] }\end{array}$ \\
\hline \multirow{2}{*}{$\begin{array}{l}\text { Gender } \\
\text { differences }\end{array}$} & Gender differences & Girls manifested greater body dissatisfaction than boys. & Tremblay et al. [19] \\
\hline & No gender differences & There were no gender differences. & Pallan et al. [26] \\
\hline
\end{tabular}

Note. The results marked with asterisk $\left(^{*}\right)$ have been evaluated with questionnaires. The results without asterisks have been evaluated with scales of silhouettes

\section{Discussion}

The aim of the present study was to examine the methodology employed to assess body image in preschoolers. We identified a wide variety of instruments and techniques used to assess body image in preschoolers, including silhouette scales, interviews and questionnaires.

\subsection{Body Image Assessment}

\subsubsection{Silhouette Scales}

Through the evaluation of body image with scales of silhouettes, it has been observed that between $27.8 \%$ [20] to $82 \%$ [26] of preschool children would like to have a different body size from the current one. Silhouette scales ordered from low to high BMI are the most frequently employed method. Some authors $[42,49]$ have suggested the need to disrupt the linear structure of silhouette scales from low to high BMI, and instead put each figure on a separate sheet, because this might increase preschoolers' accuracy.

The scales have been constructed with drawn figures [19, 
$36,38,39,41,43]$ and with photographs [12, 40]. Some authors $[12,43]$ suggested that photographic scales could have advantages in the assessment of body image in preschoolers. In this line, personalized scales may facilitate children' immersion in the task and their identification with the figure [12]. Similarly, Meers et al. [43] found that children show greater prejudice when presented with a drawn silhouette scale as opposed to photographed silhouettes. Therefore, Meers et al. [43] concluded that drawn silhouette scales might induce children to give more stereotyped responses due to confounding factors caused by reduced realism.

Although scales comprise the most commonly used instruments, there is little literature on their psychometric properties in preschool children [33]. Paxton, Spiel, Damiano, and Yager [44] found a significant agreement between $\mathrm{T} 1$ and $\mathrm{T} 2$ when selecting current figure and ideal figure. In this line, Tremblay et al. [19] observed that more than $90 \%$ of the children needed no help in the tasks. However, Li et al. [25] found no relationships between BMI and body image in the youngest participants, and Holub [33] found very low correlations between perceived and current body image, suggesting that linearly ordered silhouettes may not be a valid means to assess preschoolers' perceived body image [33]. Kean [7] decided to eliminate the younger participants from the study because of the inconsistency of their answers when administering the scales several times. In the same vein, Collins [36] has suggested that this instrument might be less valid with young children. In short, the scant literature on the validity of the scales and the discrepancy of the results reflect the need for further research.

The use of silhouette scales with preschoolers has some limitations. For example, Gardner et al. [6] have stressed that this method might not necessarily reflect participants' perceptions, since the technique obliges them to suppress their latent responses and select a solution from the scale. Furthermore, Dunphy-Lelii, Hooley, McGivern, Guha and Skouteris [49] have indicated that if the same scale is used to select current image followed by ideal image, the former may influence selection of the latter, and children may also have difficulty in making comparisons with a hypothetical ideal. However, these scales also offer advantages: they are not intrusive for children, and can provide valid results when carefully and appropriately constructed [18].

\subsubsection{Interviews and Questionnaires}

Interviews might be an appropriate methodology to help gain greater insight into, and understanding of, children's experiences of their bodies [42, 50]. Thus, Birbeck and Drummond [42] observed that some thin/average build children rejected the overweight silhouette because they associated it with receiving physical abuse and not being able to defend oneself. In conclusion, the results of qualitative research reflect that children were generally satisfied with their appearance [12-14].

Self-report questionnaires represent another method for assessing body dissatisfaction [e.g., 34]. In contrast to silhouettes scales, questionnaires have revealed a high rate of satisfaction with appearance. Tatangelo et al. [27] have advised that questionnaires for preschoolers should reflect children's attention span and involve tasks that do not last too long for very young children. In addition, it is essential to use simple vocabulary to facilitate understanding of the tasks [27].

Interestingly, no correlations have been found in this age range between body satisfaction as assessed by silhouette scales and appearance satisfaction assessed by questionnaires [16, 17]. Furthermore, Dittmar et al. [34] did not find correlations between the discrepancy between the ideal and current body (assessed by scales) and satisfaction with their appearance (assessed by questionnaire). These results suggest that the desire for thinness (assessed by scales) represents a cognitive construct that does not yet have affective consequences [16]. In other words, even when preschool girls' ideal body is thinner, they are not yet emotionally dissatisfied with their current appearance [16]. These results are in line with the findings obtained through qualitative research, in which it is observed that although four-year-old girls express some worries about the body, these concerns do not appear to impact on their general level of happiness [13]. Hence, further longitudinal research is required in order to determine the age range in which the desire for thinness might begin to be associated with the affective dimension in children.

\subsection{Body Image and Relationships with BMI, Self-esteem, Peer's Body Dissatisfaction and Dieting in Preschoolers}

The need for greater research into the body image of preschool children is reinforced by the results found in the studies: First, some investigations had found that BMI and weight status were correlated to body perception $[25,26]$ and body dissatisfaction $[15,19,25,26]$, suggesting that preschoolers may be aware of their weight and of the canons of beauty existing in society [26]. Second, positive correlations have been found between satisfaction with appearance and self-esteem in girls aged 5 to 8 years old [16] and between body dissatisfaction assessed by scales and overall body esteem [34]. In fact, the desire for thinness in girls aged between 5 and 8 years old can predict reduced self-esteem one year later [17]. These results suggest that body dissatisfaction and self-esteem are not only associated during adolescence [e.g., 32] but body dissatisfaction may also have a negative impact on young children' developing self-esteem [17]. Third, children's body dissatisfaction was associated with perceptions of their peers' body dissatisfaction $[15,16]$, suggesting that peers may be significant sources of influence on body satisfaction not only in early adolescence [e.g., 51, 52] and adolescence [e.g., 53], but also in preschoolers $[15,16]$. Fourth, only three studies have analyzed the relationships between body dissatisfaction 
and diet in preschool children. These studies have found that although body dissatisfaction was not associate with dietary restraint [21] it is associated with dieting awareness in infants [15]. Indeed, $43 \%$ of children reported that they would use some form of dietary restraint if their weight increased significantly [16]. All these results suggest the need to develop body image programs in pre-school children $[7,18,33]$ in order to prevent the onset of body dissatisfaction, unhealthy eating disordered behaviors and decrease self-esteem.

\subsection{Body Image and Cognitive Development}

In order to perform a sensitive, suitable assessment in preschool children, their cognitive development should be taken into account [5, 49]. Dunphy-Lelii et al. [49] noted that assessing body image can be difficult due to differences in the children's development in terms of their ability to perceive their current size accurately and make comparisons with a hypothetical ideal. In this line, some studies have found that more than half of the participants do not adequately perceive their body size $[19,37,43]$. Thus, in a study of children aged 3 to 5 years old, Kean [7] decided to exclude the results on 3-year old children from data analysis because of the inconsistency of their responses over time, suggesting that children under 3 years old have probably not yet developed a body image. Li et al. [25] also eliminated the results for children aged 3 and 4 years old because after analyzing the results, there were no associations between BMI and current body size. However, Tremblay et al. [19] found that most children perform well in different training tasks about identifying or estimating their body size and suggested that cognitive skills' training is appropriate during this period of development. Due to discrepancies in results, as Dunphy-Leli et al. [49] have observed, it is therefore necessary to pool the literature on body dissatisfaction and self-representation in preschool children, and identify when and how preschoolers understand their body size and shape.

As regards future areas of research, further studies are required to identify the psychometric properties of the scales and questionnaires employed, in order to gain a deeper, more reliable insight into body dissatisfaction and body perception in preschool children. In addition, there is a need for longitudinal studies of the relationship between body dissatisfaction in preschool and primary school children as assessed by scales and questionnaires, in order to identify the age range in which the desire for thinness (assessed by scales) could have affective consequences for children (such as reduced body satisfaction).

\section{Conclusions}

The most commonly used instruments to assess body image are silhouette scales, interviews and questionnaires. As indicated by Tantagelo et al. [27], the prevalence of body dissatisfaction varies markedly depending on the method used (scales, questionnaires or interviews). When body dissatisfaction is assessed by questionnaire or interview, children report being more satisfied with the way they look. One reason for the difference in the prevalence of body dissatisfaction depending on the instrument used (scale, questionnaire or interview) might be that the desire for thinness in preschoolers represents a cognitive construct that may not yet have affective consequences [16]. Regardless of the method for assessing body dissatisfaction, studies show that preschool children worry about their bodies. These results suggest the need to evaluate body image in children, since the use of body image programs at this age could prevent the development eating disordered behaviors [13]. Lastly, it is necessary to consider preschoolers' cognitive development when developing instruments to assess their body image.

\section{REFERENCES}

[1] J. K. Thompson, L. J. Heinberg, M. Altabe, S. Tantleff-Dunn. Exacting beauty: Theory, assessment, and treatment of body image disturbance. American Psychological Association, Washington, 1999.

[2] J. I. Baile. ¿Qué es la imagen corporal? Cuadernos del Marqués de San Adrián: revista de humanidades, Vol.2, 53-70, 2003.

[3] R. M. Gardner. Methodological issues in assessment of the perceptual component of body image disturbance, British Journal of Psychology, Vol.87, 327-337, 1996.

[4] Y. Wong, Y. J. Chang, C. J. Lin. The influence of primary caregivers on body size and self-body image of preschool children in Taiwan, Asia Pacific Journal of Clinical Nutrition, Vol.22, No.2, 283-291, 2013

[5] J. A. Harriger, R. M. Calogero, D. C. Witherington, J. E. Smith. Body size stereotyping and internalization of the thin ideal in preschool girls, Sex Roles, Vol.63, No.9, 609-620, 2010.

[6] R. M. Gardner, B. N. Friedman, N. A. Jackson. Body size estimations, body dissatisfaction, and ideal size preferences in children six through thirteen, Journal of Youth and Adolescence, Vol.28, No.5, 603-618, 1999.

[7] A. Kean. The Development of Body Image in Early Childhood, [PhD], Mills University. 2012.

[8] T. Asawarachan. The disney influence on kindergarten girls' body image [Ed.D.], 2013. Available from ProQuest Dissertations and Theses Global. (1506548377).

[9] E. C. Spiel, S. J. Paxton, Z. Yager. Weight attitudes in 3-to 5-year-old children: Age differences and cross-sectional predictors, Body Image, Vol. 9, 524-527, 2012.

[10] D. Musher-Eizenman, S. Holub, L. Edwards-Leeper, A. V. Persson, S. E. Goldstein. The narrow range of acceptable body types of preschoolers and their mothers, Applied Developmental Psychology, Vol.24, 259-272, 2003. 
[11] L. Smolak. Body image in children and adolescents: where we go from here? Kenyon College Department of Psychology, Gambier, OH, 2003.

[12] S. Hayes, S. Tantleff-Dunn. Am I too fat to be a princess? examining the effects of popular children's media on young girls' body image, British Journal of Developmental Psychology, Vol.28, No.2, 413-426, 2010.

[13] M. P. McCabe, L. A. Ricciardelli, J. Stanford, K. Holt, S. Keegan, L. Miller. Where is all the pressure coming from? messages from mothers and teachers about preschool children's appearance, diet and exercise, European Eating Disorders Review, Vol.15, No.3, 221-230, 2007.

[14] M. Pérez, A. M. Kroon Van Diest, H. Smith, M. R. Sladek. Body Dissatisfaction and Its Correlates in 5-to 7-Year-Old Girls: A Social Learning Experiment, Journal of Clinical Child \& Adolescent Psychology, 1-13, 2016.

[15] H. K. Dohnt, M. Tiggemann. Peer influences on body dissatisfaction and dieting awareness in young girls, British Journal of Developmental Psychology, Vol.23, No.1, 103-116, 2005.

[16] H. K. Dohnt, M. Tiggemann. Body image concerns in young girls: The role of peers and media prior to adolescence, Journal of Youth and Adolescence, Vol.35, No.2, 135-145, 2006.

[17] H. K. Dohnt, M. Tiggemann. The contribution of peer and media influences to the development of body satisfaction and self-esteem in young girls: a prospective study, Developmental psychology, Vol.42, No.5, 929-936, 2006.

[18] L. Tremblay, M. Limbos. Body image disturbance and psychopathology in children: Research evidence and implications for prevention and treatment, Current Psychiatry Reviews, Vol.5, No.1, 62-72, 2009.

[19] L. Tremblay, T. Lovsin, C. Zecevic, M. Larivière, M. Perceptions of self in 3-5-year-old children: A preliminary investigation into the early emergence of body dissatisfaction, Body Image, Vol.8, No.3, 287-292, 2011.

[20] S. Damiano, K. Gregg, E. Spiel, S. McLean, E. Wertheim, S. Paxton. Relationships between body size attitudes and body image of 4-year-old boys and girls, and attitudes of their fathers and mothers, Journal of Eating Disorders, Vol.3, No.1, $1-10,2015$.

[21] S. R. Damiano, S. J. Paxton, E. H. Wertheim, S. A. McLean, K. J. Gregg. Dietary restraint of 5-year-old girls: Associations with internalization of the thin ideal and maternal, media, and peer influences, The International Journal Of Eating Disorders, Vol.48, No.8, 1166-1169, 2015.

[22] L. Smolak. Body image development in childhood. In T. Cash, L Smolak (Eds), Body Image: A handobook of Science, Practice and Prevention. The Guildford Press, New York, 2011. P. 67-75

[23] A. Makalesi. Body Image Perceptions and Body Dissatisfaction Among Prescholers, Hacettepe Journal of Sport Sciences, Vol.24 No.3, 234-244, 2013.

[24] M. P. McCabe, D. Mellor, A. Mealey. An educational programme for parents on the body image of preschool-aged boys, Journal of Health Psychology, Vol.21, No.7, 1241-1248, 2016.
[25] Y. Li, X. Hu, W. Ma, G. Ma, J. Wu. Body image perceptions among chinese children and adolescents, Body Image, Vol.2, No.2, 91-103, 2005.

[26] M. J. Pallan, L. C. Hiam, J. L. Duda, P. Adab. Body image, body dissatisfaction and weight status in South Asian children: a cross-sectional study, BMC Public Health, Vol.11, No.21, 21-29, 2011

[27] G. Tatangelo, M. McCabe, D. Mellor, A. Mealey. A systematic review of body dissatisfaction and sociocultural messages related to the body among preschool children, Body Image, Vol.18, 86-95, 2016.

[28] J. Rodin, L. Silberstein, R. Striegel-Moore. Women and weight: A normative discontent. In Sondereregger, T. B. (Ed.), Psychology and Gender. University of Nebraska Press, Lincoln, NB, 1985.

[29] E. Stice, C. N. Marti, S. Durant. Risk factors for onset of eating disorders: Evidence of multiple risk pathways from an 8 -year prospective study, Behaviour research and therapy, Vol.49, No.10, 622-627, 2011.

[30] D. E. Nicholls, R. Lynn, R. M.Viner. Childhood eating disorders: British national surveillance study, British Journal of Psychiatry, 198(4), 295-30, 2011.

[31] S. Madden, A. Morris, Y. A. Zurynski, M. Kohn, E. J. Elliot. Burden of eating disorders in 5-13-year-old children in Australia, Medical Journal of Australia, 190(8), 410-414, 2009.

[32] I. Brechan, I. L. Kvalem. Relationship between body dissatisfaction and disordered eating: Mediating role of self-steem and depression, Eating Behaviors, Vol.17, 49-58, 2015.

[33] S. C. Holub. Individual differences in the anti-fat attitudes of preschool-children: The importance of perceived body size, Body Image, Vol.5, No.3, 317-321, 2008.

[34] H. Dittmar, E. Halliwell, S. Ive. Does barbie make girls want to be thin? the effect of experimental exposure to images of dolls on the body image of 5- to 8-year-old girls, Developmental Psychology, Vol.42, No.2, 283-292, 2006

[35] D. Moher, A. Liberati, J. Tetzlaff, D.G. Altman, Group P, Preferred reporting items for systematic reviews and meta-analyses: the PRISMA statement, Journal of Clinical Epidemioly, Vol.62, 1006-1012, 2009.

[36] M. E. Collins. Body figure perceptions and preference among preadolescent children, International Journal of Eating Disorders, Vol.10, 208-217, 1991.

[37] J. N. Burgess, M. E. Broome. Perceptions of weight and body image among preschool children: A pilot study, Pediatric Nursing, Vol.38, No.3, 147-176, 2012.

[38] M. Tiggemann, B. Pennington. The development of the Children's Body Image Scale, British Journal of Clinical Psychology, Vol.41, 185-203, 1990

[39] M. Tiggemann, E. Wilson-Barrett. Children's figure ratings: Relationship to self-esteem and negative stereotyping, International Journal of Eating Disorders, Vol.23, 83-88, 1998. 
[40] H. Truby, S. J. Paxton. Development of the Children's Body Image Scale, British Journal of Clinical Psychology, Vol.41, 181-203, 2002.

[41] Z. Mciza, J. Goedecke, N. P. Steyn, K.E. Charlton, T. Puoane. Development and validation of instruments measuring body image and body weight dissatisfaction in South African mothers and their daughters, Public Health Nutrition, Vol.8, No.5, 509-519, 2005.

[42] D. Birbeck, M. Drummond. Very Young children's body image: Bodies and minds under construction, International Education Journal, Vol.7, No.4, 423-434, 2006.

[43] M. R. Meers, A. M. Koball, M. W. Oehlhof, K. R. Laurene, D. R. Musher-Eizenman. Assessing anti-fat bias in preschoolers: A comparison of a computer generated line-drawn figure array and photographic figure array, Body Image, Vol.8, No.3, 293-296, 2011.

[44] Paxton SJ, Spiel EC, Damiano SR, Yager Z. The Children's Body Image Development Study. Unpublished raw data. Melbourne, Australia: La Trobe University; 2010.

[45] C. S. W. Rand, J. L. Resnick. The "ood enough" body size as judged by people of varying age and weight. Obesity Research, Vol.8 No.4, 309-316, 2000.

[46] B. K. Mendelson, D. R. White, M. J. Mendelson. Self-esteem and body esteem: Effects of gender, age and weight, Journal of Applied Developmental Psychology, Vol.17, 321-346, 1996.
[47] S. Harter, R. Pike. The pictorial scale of perceived competence and social acceptance for young children, Child Development. 55: 1969-1982, 1984.

[48] M. Perez, A. M. Kroon Van Diest. Development and validation of an interview for 5 to 7 year olds girls on body dissatisfaction/satisfaction, thin ideal internalization, and self-objectification, Manuscript under review.

[49] S. Dunphy-Lelii, M. Hooley, L. McGivern, A. Guha, H. Skouteris. Preschoolers' Body-Knowledge Inaccuracy: Perceptual Self-Deficit and Attitudinal Bias, Early Child Development and Care, Vol.184, No.11, 1757-1768, 2014.

[50] I. Seidman. Interviewing as qualitative research: A guide for researchers in education \& the social sciences. Teachers college, New York, 2013.

[51] L. Clark, L., M. Tiggemann. Appearance culture in 9- to 12-year-old girls: Media and peer influences on body dissatisfaction, Social Development, Vol.15, 628-643, 2006.

[52] A. Amaya-Hernández, M. Ortega-Luyando, M. L. Bautista-Díaz, G. L. Alvarez-Rayón, J. M. Mancilla-Díaz. Children with obesity: peer influence as a predictor of body dissatisfaction, Eating and Weight Disorders - Studies on Anorexia, Bulimia and Obesity, 1-7, 2017.

[53] U. Kenny, M. P. O’Malley-Keighran, M. Molcho, C. Kelly. Peer Influences on Adolescent Body Image: Friends or Foes?, Journal of Adolescent Research, 1-32, 2016. 